\title{
Science, mathematics and technology education in the US: a perspective from the "frontlines of the classroom to national policy"
}

\author{
R. A. Pertzborn \\ Office of Space Science Education, Univ. of Wisconsin-Madison, 1225 West Dayton Street, Madison, Wisconsin 53706, USA
}

Received: 6 December 2004 - Revised: 14 March 2005 - Accepted: 15 March 2005 - Published: 16 June 2005

\begin{abstract}
In the past decade significant emphasis has been placed on increasing the involvement and influence of the professional scientific community in America's K-12 classrooms. The origins of this thrust have arisen from a variety of real and perceived crises occurring in America's K-12 classrooms. Projections for the nation's future workforce needs indicate an increased demand for science and technically literate workers, while fewer of the nation's students are pursuing advanced degrees in these academic areas of expertise. In an effort to address these issues and to impact the overall understanding and quality of science, math and technology education, several of the federal agencies have increasingly included a percentage of research funding devoted to the objective of improving the quality of kindergarten through Grade 12 (K-12, see Table 1) formal education and informal public outreach. To this end, NASA's Space Science Enterprise in particular has demonstrated a successful implementation approach and has been a national leader in forging strong partnerships with the education community to address these concerns.
\end{abstract}

\section{A brief history: perceived problems and solutions}

"Hell is paved with good intentions, not with bad ones. All men mean well." George Bernard Shaw

Since 1960's, essentially in the post-Sputnik era, there have been quite a few attempts at "fixing" education in the US (Bassett, 2002). Some general observations can be made regarding these as follows:

- Most education reform initiatives have been the result of a perceived (and occasionally real) political or economic crisis.

Correspondence to: R. A. Pertzborn

(RoseP@ssec.wisc.edu)
- Public education has been an easy target by politicians, business leaders and others with an agenda or desire to find a convenient scapegoat.

Particularly in the area of Science and Math education, the efforts since the early sixties have been met with mixed success, despite huge amounts of resources devoted by the National Science Foundation, culminating in recent International Math Science Studies concerning science knowledge achieved by school students that show US students lagging behind the leaders (TIMSS, 1999; International Study Center at Boston College). This led to an effort by the National Science Foundation to evaluate its systemic efforts in Science and Math education programs through the five year effort led by the National Institute for Science Education at the University of Wisconsin-Madison. There are several well known initiatives to improve the quality of science education in partiticular in the US, and the National Academy of Sciences has published guidelines for science education standards (NRC, 1996) for elementary, middle and high schools (Table 1).

2 More solutions... and the "law of unintended consequences..."

- Solution: Junior High Schools change to Middle Schools. Change learning focus from subject areas and content to development of students' self esteem, exploration of wide ranging topics (interdisciplinary learning) to encourage curiosity/creativity and optimize opportunities to succeed.

- Unintended consequence: Middle grades have become redundant, shallow, content is inconsistent and student achievement has suffered!

- Solution: Teachers who were certified for 7-12 in their subject area are now certified for 1-8 or middle school. Professional development and education courses taught teachers to focus more on child emotional development and not on academic achievement. 
Table 1. US Schools: General age range, grade levels and categories.

\begin{tabular}{lll}
\hline General Age Range & Grade Level & School Type \\
\hline $5-10$ & Kindergarten-5 & Elementary \\
$11-13$ & $6-8$ & Middle \\
$14-18$ & $9-12$ & High School \\
\hline
\end{tabular}

- Unintended consequence: Most middle school teachers have limited (and frequently no) background coursework in the subject areas they teach (especially science and mathematics). National average student performances in science and mathematics (middle to upper grades) have plummeted as compared to other nations around the world.

\section{Current issues}

\subsection{Future workforce needs}

One of the main drivers for the current focus on Science and Math education is the perceived future need by the nation for trained scientists and engineers to staff its key "engines" advanced research and national security. The key national research laboratories and the defense industry have become increasingly reliant on the availability of overseas trained or schooled (partly or wholly) professionals in key areas due to a lack of US born students pursuing careers in those areas. It is becoming an increasingly serious issue that US students are turning away from science and to a lesser extent, engineering careers, beginning with the high school age group. The availability of foreign born graduates has been facilitated by the educational opportunities available to them in US institutions of higher education. In fact, US graduate schools have become increasingly dependent on the supply of foreign born students to a significant degree.

The impact of the foreign born students has been felt on many of the universities, particularly graduate schools after attacks on 11 September 2001. Among the top 25 US research universities $(60 \%)$ that admit the most foreign students, there has been a $30 \%$ decline in the number of applications (Detroit News, 24 March 2004). If this trend continues, it will likely impact the number of the foreign born, US trained graduates that enter the workforce in the US, on whom the US currently depends to fill workforce needs.

There are additional relevant factors as well:

- Comparable opportunities are luring foreign students home. Nations that once supplied much of the US foreign Science \& Engineering workforce, such as South Korea, now have the ability to provide their own students and graduates with first-world opportunities. Other countries, such as China, are moving swiftly in the same direction.
- "Stay rates" of foreign scientists and engineers cannot rise much farther: "Stay rates" of foreign students have been both stable and relatively high. Between 1994 and 1999, the overall rate was 63 percent.

- The ability to recruit talent from abroad may be limited in the future. Historically, the United States recruited globally and had access to the best minds worldwide. Several factors may reduce this source. Legislative pressure to restrict immigration increased in the wake of 11 September 2001. Several bills have been passed into law since 11 September to prevent suspected terrorists from entering the United States through loopholes in immigration laws and the nation's visa system.

Much effort has been invested in understanding why so few US born students enter science and engineering careers. However, the real reasons may be more basic:

- Students are not adequately prepared for the rigors of college level curriculum in science, engineering and mathematics, therefore

- College faculty have great difficulty targeting courses to ability level of students because of vast ranges and inconsistencies in student preparedness, resulting in

Increasing dropout rate as subject matter becomes more advanced, requiring increased focus and depth (which they have not been prepared for in pre-college education!!)

\subsection{Teacher professional development needs}

"A federally funded study recently showed that students learn more when their teachers have knowledge of the subject. . Along with Homer Simpson, I responded, "D'oh!"

From: This Just in... The Equator passes through Florida, by Dr. Walter A. Lyons. Bulletin of the American Meteorological Society, July 2003.

Among reasons cited for the lack of US students choosing a career in sciences, particularly physical sciences or engineering are a lack of qualified teachers and the perception that "science is hard". Perhaps even more significant and relevant may be the traditional, cultural reasons, such as - only nerds do science while others, are economic - other careers are more lucrative. In dispelling or sustaining these valid or perceived reasons for not choosing a science career, the role of the nation's teachers cannot be ignored. A survey of teachers in middle and high schools shows a preponderance of teachers of science with inadequate or even a total absence of any prior formal preparation in the content areas they teach. Further, among those who have a science background, almost $75 \%$ are likely to be prepared in biological science with no background in the physical sciences.

In the most advanced country in the world, there is a significant gender inequity in the science careers, the causes for which are primarily cultural. The disparity continues through overt and covert discrimination even at the leading academic 
Table 2. Perceived problem and the solution.

\begin{tabular}{ll}
\hline Perceived problem & Solution \\
\hline $\begin{array}{l}\text { The failure of the U.S. to put a satellite in orbit around the } \\
\text { earth ahead of the U.S.S.R. was blamed on the education } \\
\text { system. }\end{array}$ & $\begin{array}{l}\text { In response to Sputnik, a significant increase in math and science } \\
\text { along with student "tracking" by ability level so more engineers could } \\
\text { be produced. }\end{array}$ \\
$\begin{array}{l}\text { Public education is blamed for problems associated with } \\
\text { racial integration and the Vietnam war. }\end{array}$ & $\begin{array}{l}\text { A new focus on curriculum "relevance" and de-emphasis on the clas- } \\
\text { sics. Con-current with "open-space" classrooms without walls and } \\
\text { "new math." }\end{array}$ \\
$\begin{array}{l}\text { The Japanese and German economies were getting } \\
\text { stronger while the U.S. economy was losing its global } \\
\text { standing. }\end{array}$ & $\begin{array}{l}\text { The report "A Nation at Risk" once again placed most of the blame } \\
\text { on public education. } \\
\text { Reality: education had nothing to do with economic prob- } \\
\text { lems...Rising oil prices and various economic problems rested } \\
\text { squarely on poor corporate planning (particularly automakers). }\end{array}$ \\
\hline
\end{tabular}

institutions, resulting in a lack of sufficient numbers of female role models, both as (science/mathematics) teachers and successful career scientists and engineers.

There is a demonstrated need for professional development of teachers in the (physical) sciences. This need has been recognized and discussed in the National Standards for Professional Development in a recent report by the National Research Council (1996).

Regarding the teaching of science in the US schools at present, certain observations can be made:

- Space Science and the topics it encompasses including physical and biological sciences as well as applied math, remains one of the most broadly appealing and motivating topics for students across all grade levels.

- Most schools in the US do not address earth, physical and space science content adequately even though it is required by most state's science standards.

- Most teachers have minimal current knowledge of earth, physical and space science topics.

The obvious would be to meet the primary needs of the teachers by supporting them and School Districts in the development of standards-based curriculum by taking steps to accomplish the following (Horsley et al., 1998):

- Insure curricular materials include the most current (and appealing) space science content and topics.

- Address unique professional development goals/needs of individual teachers.

- Create professional development opportunities for teachers to meet with content experts (Scientists) on a regular (minimum of one week-long workshop in summer and three one-day sessions during the school year) to collaborate with one another to develop improved classroom materials.
Table 3. Percentage of graduate degrees in science and engineering conferred to foreign students, by degree level and field of study: Academic year ending 1994. SOURCE: U.S. Department of Education, National Center for Education Statistics, Digest of Education Statistics, 1996 (based on IPEDS/HEGIS surveys of degrees conferred).

\begin{tabular}{lcc}
\hline Field of study & Master's & Doctor's \\
\hline Total & 12.0 & 26.7 \\
Total science and engineering & 31.3 & 40.9 \\
Natural sciences & 25.4 & 33.5 \\
Life sciences & 18.0 & 27.5 \\
Physical sciences & 31.1 & 35.6 \\
Mathematics & 26.7 & 48.5 \\
Computer Science and engineering & 33.5 & 52.3 \\
Computer and information sc. & 37.5 & 44.8 \\
Engineering & 32.1 & 53.3 \\
\hline
\end{tabular}

The strategies that are most likely to be effective are to:

- Exploit high interest and appealing subject matter, i.e. Space Sciences!!

- Focus on building knowledge and provide opportunities for teachers to increase their understanding of science content and math applications.

- Work collaboratively with practicing scientists to focus on improving content knowledge, instructional materials, access to data and research facilities to acquire new information.

\section{Best approaches for effective teacher training}

- Teachers partnering with other teachers from same school extremely motivating for continued involvement with program and classroom utilization. 
- Regular meetings that build sustained relationship/partnerships between teachers and scientists essential for eventual classroom implementation of curriculum.

- Learning Cohorts including middle school through high school earth science and physics teachers as well as community college teachers to provide an excellent opportunity for creating educational materials that represent the continuum of changing student cognitive abilities and needs.

\section{NASA's Office of Space Science: one agency's solution}

\section{Understanding the Risks to the Science and Engineering Workforce}

In recent times, efforts have been made not only in the private and non-profit sectors but also in a variety of federal departments and agencies to determine the nature of the risks and the consequences to the United States of undervaluing and relying on market forces to engender an adequate $\mathrm{S} \& \mathrm{E}$ workforce. Taken singly, no one risk is debilitating. Taken together, there is substantial cause for concern.

The federal Science \& Engineering workforce is shrinking: The Department of Defense Science \& Engineering workforce declined from 45000 to 28000 in the decade between 1990 and 2000. Many more will soon retire. Other agencies reflect the same pattern. Approximately 45 percent of all scientists and engineers employed in the federal government are 45 years of age or older. Federal agencies have not hired scientists and engineers in significant numbers in recent years.

The NASA Office of Space Science's Unique Strategy as described by Rosenthal et al. (2004):

- Attempts to bring unique and exciting Space Science research/content to:

- The general public (Public Outreach)

- And the formal education community including teachers and students.

Scientist involvement:

- Focus on Scientists partnering with the community / educators to bring their unique and exciting research to the public and into the classrooms of America.

- Scientists are required to develop an Education and Public Outreach (E/PO) Program in conjunction with all Space Flight Missions!!!

- Partnerships with educators are required to insure classroom usability of all materials developed!

- Additional funded opportunities for Scientists to do E/PO are available through other Grants.
- All E/PO proposals are peer reviewed to insure overall quality and effective program implementation.

\section{Conclusions}

In order to tackle the numerous challenges and exploration vision in the next century, a well-informed public and an adequately prepared workforce is essential. In many developed nations of the world the science and engineering enrollments are declining as fewer students are choosing careers with only a few exceptions. There is currently a mismatch between the available trained workforce and the needs of the many fields of science and engineering. A key reason given for this situation is that at an early age, many students are not motivated enough to learn science and choose science and technology careers (computer science excepted). In some cases the choices are driven by future perceived earnings. Space exploration provides ample excitement and "hooks" the interest of many students, which is essential to motivate them to pursue science and the diversity of educational experiences to create the workforce needed in space exploration. This type of training is also critical in addressing other important challenges facing future generations, including such international issues as global change.

Acknowledgements. It is a pleasure to acknowledge the travel support provided by the European Geophysical Union and the support provided by the Space Science and Engineering Center and the University of Wisconsin-Madison for vigorously supporting outreach and education activities in Space Sciences. A special thanks to my colleague S. Limaye for his assistance.

Edited by: N. Crosby

Reviewed by: K. Stegen and N. Crosby

\section{References}

Bassett, F.R.: Block Scheduling, Educational Reform Efforts, Education News.Org., http://www.educationnews.org/ Educational $\{\backslash \%\} 20$ Reform $\{\backslash \%\} 20$ Efforts.htm, 2002.

Loucks-Horsley, S., Hewson, P. W., Love, N., and Stiles, K. E.: Designing Professional Development for Teachers of Science and Mathematics, Corwin Press Inc., Thousand Oaks, California, 325 pp., 1998.

Lyons, W. A.: This Just in... The Equator passes through Florida, Bulletin of the American Meteorological Society, 84, 891-892, 2003.

Martin, M. O., Mullis, I. V. S., Gonzalez, E. J., Gregory, K. D., Smith, T. A., Chrostowski, S. J., Garden, R. A., and O'Connor, K. M.: TIMMSS 1999 International Science Report: Findings from IEA's Repeat of the Third International Mathematics and Science Study at the Eight Grade, The International Study Center, Lynch School of Education, Boston College, Chestnut Hill, MA 02467, ISBN 1-889938-16-5, http://www.timss.org/, 2000.

National Research Council: The National Science Education Standards, National Academy Press, Washington D.C., 262 pp., 1996. 
Rosendhal, J., Sakimoto, P., Pertzborn, R., and Cooper, L.: The NASA Office of Space Science Education and Public Outreach Program, Advances in Space Research, 34, 2127-2135, 2004.

TIMSS: International Mathematics Report: Fndings from IEA's Repeat of the Third International Mathematics and Science Study at the Eighth Grade, 1999.
TIMSS: International Science Report: Findings from IEA's Repeat of the Third International Mathematics and Science Study at the Eighth Grade, Mullis, I. V. S., Martin, M. O., Gonzalez, E. J., Gregory, K. D., Garden, R. A., O'Connor, K. M., Chrostowski, S. J., Smith, T. A., available at: http://timss.bc.edu/timss1999i/ math_achievement_report.html, 1999. 